\title{
How can ethics relate to science? The case of stem cell research
}

\begin{abstract}
Ana Sofia Carvalho ${ }^{\star, 1}$ and João Ramalho-Santos ${ }^{2,3}$
We live in an era of an important turning point in the relationship between ethics (or, more accurately, bioethics) and science, notably due to both public interest and the gradual tightening of the gap in time between scientific discoveries and ethical reflection. The current bioethics debates of emerging situations (pluripotent stem cells, gene therapy, nanotechnology) have undoubtedly contributed to this change. Today, science happens and bioethics reflects on the possibilities, considers the risks, and advances proposals, which, without being scientific, can also imprint a mark on the path of scientific development. In this article, through the narrative of stem cell research, we will try to illustrate how bringing a bioethical viewpoint to the scientific debate can become a healthy exercise in both ethics and science, especially as narratives shift, as was the case in this field due to the introduction of induced pluripotent stem cells, the advent of which is not easily dissociated from the controversies related to embryo research. We should perhaps welcome this trend as promising for the future relationship between ethics and scientific research, providing a stimulus (and not a block) to the ever-evolving scientific discourse.
\end{abstract}

European Journal of Human Genetics (2013) 21, 591-595; doi:10.1038/ejhg.2012.232; published online 14 November 2012

Keywords: bioethics; ethics; science; stem cells; embryo; induced pluripotent stem cells

\section{INTRODUCTION}

The debate on stem cell research, together with the ethical questions the respective technologies have raised, has entailed intense and passionate discussions within the most diverse sectors of society. These discussions, often highlighted by interests that are neither scientific nor ethical, must not necessarily be considered as good exercises in either ethical reflection or scientific education.

Bioethics has been called to intervene within the framework of science mainly in three different ways: (a) by imposing limits, in a repressive action, determined by the fear of the unprecedented or unknown; (b) through the elaboration of rules, thus in terms of a regulatory action due to legal requirements; and (c) through education and awareness. ${ }^{1}$ However, it is important to stress that in our opinion bioethics is not useful if it degenerates into a mere 'repair' of technical deficiencies and weaknesses, or a stop-gap and/or after-thought exercise. Bioethics should not hamper progress, but rather promote constant refocusing. 'What should I do?' together with 'How do I do it?' should be the questions of choice and not necessarily 'what can I do?' It is crucial, in our view, that in this strategy of reorientation, science becomes aware of and permeable to the ethical concerns, and likewise ethics finds the sensitivity to become permeable to scientific issues.

Today, ethical reflections appear as an important part in any field of scientific research. We would like to highlight some factors involved in the narrowing of the relationship between ethics and science and it may be important to justify the interest in the area of bioethics, at several levels, notably among non-scientists. ${ }^{2}$

The core issues of reflection of bioethics have also recently suffered considerable fluctuations. Initially, the main focus had been problems that were drawn from concrete medical practice. Indeed, in this particular realm (especially involving clinical trials and the introduction of novel therapies to patients) one should note that arguments have been made in terms of considering ethics reviews as a possible (unethical) hindrance to medical progress by causing delays and not being cost-effective (see, eg, Whitney and Schneider ${ }^{3}$ ). However, immediate applications are not the focus here. In fact, we could consider the rebirth of the broad concept of bioethics originally proposed by Potter. ${ }^{4}$ An important adjustment could be pointed to as a reason for this change: the movement from an agenda with only persistent areas (abortion, euthanasia, and others) to an agenda with puzzling emerging and new areas (cloning, gene therapy, stem cells, nanotechnology, among others). This exercise of thinking the ethical before the scientific (or in parallel with it) enabled an important approach between science and ethics. Importantly, the transdisciplinary nature of bioethics, is important in two different ways: on the one hand, it calls upon different authors-the philosopher, biologist, physician, nurse, pharmacist, lawyer, theologian-for reflection; and on the other, it must reach the different audiences involved and become intelligible to a significant fringe of the population who still feels excluded from the scientific debate, thus encouraging reflection and society participation in these topics. Other factors, more external perhaps, such as political, economic, religious, social and media exposure, among others, must also be considered in order to understand this new relationship between ethics and science.

Science, here used as technoscience (ie, in conjunction with technology), has increasingly been subject to economic pressures at several levels, involving return of investment considerations from both

${ }^{1}$ Centro de Investigação em Bioética, Instituto Bioética da Universidade Católica, Porto, Portugal; ${ }^{2} \mathrm{CNC}$ - Center for Neuroscience and Cell Biology, University of Coimbra, Coimbra, Portugal; ${ }^{3}$ Department of Life Sciences, University of Coimbra, Coimbra, Portugal

*Correspondence: Professor AS Carvalho, Centre of Research in Bioethics, Institute of Bioethics, Rua Diogo Botelho 1327, Porto 4169-005, Portugal. Tel: + 00351919184384 ; E-mail: acarvalhoporto@ucp.pt

Received 27 April 2012; revised 21 August 2012; accepted 6 September 2012; published online 14 November 2012 
private and public agents. The slower pace of bioethical reflection had thus to be adapted to withstand compelling pressures of financial and political priorities, as scientific issues have never had such a significant presence in the political agenda. ${ }^{5}$ Society can feel increasingly challenged by scientific issues, and when faced with the difficulties inherent to scientific understanding, even perhaps experience some measure of vulnerability due to several factors. This is especially visible in topics related to the human body and reproduction. As stated by Luís Archer, it is quite possible that the popularity of bioethics derives in part from an instinctive voice of society in order to compensate the dehumanizing technologism of 'bio' (the details of which are limited to a few experts, and that society tends to never fully understand as a whole) with humanist considerations of 'ethics' (to which most, if not all, elements of society can contribute). ${ }^{6}$

The media have also had a central role in this issue. Despite the emergence of many well-prepared and insightful science bloggers, in many cases the goal seems to be to stir up controversy and even avoid consensus by fostering radical positions that are often not even representative, with the popularization of erroneous concepts despite recent efforts to encourage both education and the participation of society in science policy discussions. The extensive airtime given to those who promised to (successfully) perform human cloning at the end of the previous century is a good example of this, as coverage was purely dependent on ethical narratives, disregarding the glaring technical issues clear from model animal experiments (from 'Dolly, the sheep' onwards), which put such efforts beyond reasonable plausibility. ${ }^{7}$ Importantly, it should be also be noted that many practicing scientists consider Science as a self-correcting enterprise, and that, in the long run end, the mechanisms for validation work with no great need for regulatory or non-scientific discussions. But these mechanisms could be painfully slow, and in the meantime, there are policies to implement and decisions to be made. ${ }^{7}$

\section{STEM CELL RESEARCH: ETHICS AND SCIENTIFIC CROSSROADS}

We begin with a necessarily brief overview of stem cell research. We will first introduce a few general concepts and note previous debates that were important in stem cell research but have now become, in practice, obsolete (such as that concerning cloning) before mentioning the novel-emerging avenues, namely those involving induced pluripotent stem cells (IPSC) where more bioethical reflection would be welcome.

The essential characteristics of all stem cells are their ability for selfrenewal and the ability to form one or more specialised cell types over time $^{8-10}$ A distinction is usually made between the different types of stem cells according to origin, degree of differentiation and especially developmental potential. With regard to differentiation properties, there are different types of stem cells: pluripotent, multipotent and unipotent. ${ }^{11-14}$

The fertilized human egg cell is totipotent (but not really a stem cell, as it cannot self-renew), meaning that it has full potency. The first mitotic divides the zygote into two blastomeres, which then subsequently divide to form four and eight cell embryos. These cells are not yet specialized and any one of them can theoretically develop into a new organism if implanted in the uterine mucosa. However, it should be noted that the early embryo has a truncated cell cycle and that each division results in more cells that are progressively smaller. The decreasing amount of cytoplasm per cell progressively reduces the potential of forming a complete individual, even though the cell nucleus may maintain this capability. ${ }^{15}$ Around the fourth or fifth day of development, the first lineage specification becomes obvious when a peripheral layer (the trophoblast) is formed. This layer is responsible for the embryonic contribution to the placenta, while the inner cell mass or pluriblast, remains undifferentiated. The cells of the inner cell mass, called pluripotent embryonic stem cells, will continue to develop and can make any type of cell derived from any of the three embryonic germ layers (ectoderm, endoderm and mesoderm) and some extraembryonic structures, without, however, being able to contribute to the placenta. After implantation, they differentiate into committed cells with specific lineages and particular functions; these more committed cells are multipotent or unipotent, depending on the cell types that arise from them. However, in this case the cell types generated are limited and more focused on one germ layer.

The pluripotent cell lines derived from the inner cell mass and removed from the biological context of the embryo are called embryonic stem cells. These cells can remain undifferentiated in culture, essentially maintaining the properties of the pluriblast, with the innate ability of forming any cell type provided the appropriate differentiation cues are provided. ${ }^{8,9}$ Finally, we have stem cells isolated from adults, that is, adult stem cells. Adult stem cells share at least two characteristics with embryonic stem cells; ${ }^{16}$ (a) the capacity for selfrenewal and (b) the possibility to create differentiated cells with characteristic morphologies and specialized functions. On the other hand, and crucially, they have been found to be (reproducibly) only multipotent or unipotent, not pluripotent.

The interest of stem cells in basic research should not be confused with possible translational applications. Embryonic stem cells were always known to pose problems in terms of clinical applications, namely for three reasons: (a) the difficulty in obtaining pure differentiated and functional cells in large numbers; (b) the tumorogenic potential that is associated with pluripotency, and (c) the possibility of rejection upon transplantation, as, being isolated from embryos, these cells would not be identical to any existing patient. On the other hand, the use of embryonic stem cells in terms of studying mammalian differentiation and oncogenesis in vitro, and as tools in potential pharmacological and toxicological screening (eg, reducing animal testing), has shown promise.

The first stem cells to have been applied clinically were adult (hematopoietic) stem cells, which have been used for decades in bone marrow transplantation, ironically with the expression 'stem cell' being associated with this procedure many years after it was proven highly successful. Unsurprisingly, adult stem cells are currently at the forefront in potential future transplantation strategies. In the most recent studies, research has been essentially based on the use of mesenchymal stem cells isolated from the umbilical cord blood, umbilical cord matrix and bone marrow. ${ }^{17,18}$

However, it is important to highlight that there is still a long way to go in this area, and subsequent studies should demonstrate unequivocally (a) differentiation into functional somatic cells that integrate into existing tissues allowing recovery in vivo; (b) the non-formation of tumors; (c) the availability in sufficient number (and/or consequent expansion) of useful cells; and (d) that the results reported are reproducible in a variety of scientific and clinical settings (this has been a main cause of concern in the field).

\section{PLURIPOTENT STEM CELL RESEARCH: EMBRYO DESTRUCTION VERSUS NON-EMBRYONIC SOURCES}

From the start embryonic stem cell research was marred by controversy, given that the standard production method involves the destruction of human embryos. It is equally clear that the attitude adopted in this case depends on the relative position as to the status 
of the embryo, a position that is far from being consensual. From an interview given to the New York Times on 22 November 2007, ${ }^{19}$ Jamie Thomson, the creator of the first human embryonic stem cell lines, notes: 'If human embryonic stem cell research does not make you at least a little bit uncomfortable, you have not thought about it enough.'

This explains the many elaborate (and even convoluted) strategies proposed, some more feasible than others, which allowed for the harvesting of cells with 'stemness' characteristics while minimizing embryo destruction. ${ }^{20}$ The introduction (and lengthy discussion) of alternatives had clearly more to do with bioethical concerns than that with scientific issues. These proposals could be divided into two main groups: those that involved embryos or oocytes in a manner that would reduce bioethical concerns; and those that tried to use non-embryonic stem cells in novel ways, so as to sidestep the issue entirely. The second group includes adult stem cells, or cells harvested from amniotic fluid or umbilical cord. As discussed above, these stem cells are already committed to a specific cell line. However, this commitment may not be as definitive as was initially thought, and some studies suggested that adult stem cells may give rise to specialised cell types of a tissue, other than that from which they originated. ${ }^{21-26}$ However, the practical use of this sort of phenomena has to be treated with care, as previously reported experiments on this topic in the past ${ }^{27}$ have been shown to be non-reproducible. Therefore, adult stem cells are more realistically being proposed as a possible source of material to treat the tissue of origin or closely related tissues. ${ }^{28}$ Another aspect that is often neglected relates to the fact that research with adult stem cells may not result necessarily in applications involving transplantation of cells cultured and modified ex vivo but lead to strategies focusing on interventions stimulating resident stem cells in the body. Going back in developmental time, stem cells from the amniotic fluid and umbilical cord seem promising, ${ }^{18}$ but, again, whether the unexpected pluripotency reported in some studies is reproducible and reliable remains an unresolved issue.

In terms of strategies involving oocytes and embryos, several proposals were also advanced. The use of surplus embryos resulting from medically assisted procreation techniques was perhaps the most discussed, but ethical objections remain due to considerations regarding the nature of the human embryo, namely whether there is an expectation of it being brought to term or not. In this regard, using embryos that are unviable, either because they have anomalies preventing them from implanting or because they have stopped developing, might be a better option, as these embryos can still produce pluripotent embryonic stem cell lines. ${ }^{29}$ The difficulty of this approach lies primarily in the criteria for embryonic death.

A related proposal posited the creation of a genetically altered embryo so as to attain the blastocyst stage but prevent any possibility for implantation. ${ }^{30}$ However, pre-engineering a cell so as to reduce its future developmental potential seems a rather convoluted procedure, from both a scientific and a bioethical perspective.

Another strategy is embryo biopsy. ${ }^{31}$ The method uses the technique used in pre-implantation genetic diagnosis to remove an embryo biopsy and develop embryonic stem cell lines without compromising implantation. However, not only is there the possible difficulty of considering the biopsy itself totipotent (and therefore worthy of protection), but it also seems naive to assume that embryo viability would not be affected by the procedure, and a more ethical possibility might be to use this technique only on embryos that were already undergoing pre-implantation genetic diagnosis. Yet another strategy is parthenogenesis ${ }^{32}$ where an oocyte is stimulated to develop as if it had been fertilized. Parthenogenetic embryos have grown to the blastocyst stage (when pluripotent stem cells are harvested), although these cells show differences when compared with other embryonic stem cells.

Finally, one issue that lingered in all the strategies noted above is that of genetic matching of cells with putative therapeutic potential to a specific patient. With the exception of using the patient's own adult stem cells all other strategies ignore this issue. It is in this context that cloning/somatic cell nuclear transfer (SCNT) must be understood and discussed. This technique would constitute a source of cells with a pre-determined genetic make-up and involves transferring the nucleus of a somatic cell taken from an individual to an enucleated oocyte, reprogramming this nucleus in the resulting construct, and then isolating and differentiating the immunologically compatible patientspecific embryonic stem cells. SCNT was thus intimately involved in the debate on stem cell research, as a possible strategy for avoiding immunological complications. A central ethical question that was immediately considered in this case was whether the cloned embryo differs from any other embryo. Terms such as: 'embryonoid', 'nuclovule', 'activated cell' and 'technical artefact' were suggested for the result of cloning by nuclear transfer, on the grounds that there were no plans for implantation. ${ }^{33,34}$ Using the same argument, but now in order to cast doubt, other authors claim that as it is alive and one cannot exclude the possibility of it developing into a new human life, it differs in no essential way from another embryo. ${ }^{35}$ However, the creation of embryos through SCNT entailed countless technical difficulties, including the need for an extremely high number of oocytes. In fact, although basic scientific questions may still be answered with this technique, the therapeutic implications of SCNT can now be considered null also from a scientific standpoint, leading this discussion to semi-irrelevant status except in terms of the historical context.

Indeed, many of the discussions noted above involving embryos, while certainly valid, are no longer at the cutting edge of research, as the field of stem cells was completely shifted following the introduction of IPSC by Yamanaka and collaborators. ${ }^{36,37}$ These studies demonstrate the possibility of reprogramming adult somatic cells into pluripotent stem cells that mirror embryonic stem cells, using the forced expression of genes shown to be essential in maintaining the main characteristics of embryonic stem cells. ${ }^{38}$ IPSCs can then be differentiated into all cell types of interest although it should be noted that embryonic stem cells are still viewed as a 'golden standard' for pluripotency studies, ${ }^{39}$ and there may be important epigenetic and genomic instability differences in IPSC relative to this standard that may be relevant for future clinical applications. ${ }^{40-44}$

Nevertheless, it is fair to say that current translation-oriented pluripotent stem cell research focuses mostly on IPSC and that embryo-based research is more focused on the study of the embryo itself. There are several reasons for this, namely: (a) It is technically simple, certainly much simpler than SCNT; (b) cells from an adult patient can be used, thus ensuring genetic compatibility; (c) the reprogramming of somatic cells takes place without oocytes or the need to discuss embryo status; and (d) it was immediately shown to be extremely reproducible, again unlike SCNT which, in humans, was further marred by the Woo-Suk Huang fraud. Indeed the therapeutic strategies tested in model animals with SCNT were quickly and successfully repeated using IPSC.

To what can the success of this development be due? Basic science efforts, as a reaction to technical difficulties regarding both access to oocytes and SCNT, or even because of some unwillingness to deal with ethical issues? Probably a mixture of circumstances. Shinya Yamanaka has famously (and repeatedly) stated that to obtain IPSC 
'neither eggs nor embryos are necessary. I've never worked with either, ${ }^{45}$ and, although with the benefit of hindsight, it seems unlikely that the difficulties in working with embryos did not play a part in the active search for alternatives that ultimately resulted in IPSC.

Nevertheless, in spite of these surprising developments, it must be stressed that many issues related to the putative use of embryonic stem cells are also valid for IPSCs: (a) the need for efficient differentiation into cells of interest; (b) unequivocal demonstration that, when transplanted, the cells allow for damage recovery in vivo; (c) the tumorogenic potential of IPSC is the same as that of embryonic stem cells; and (d) the success of proof of principle strategies in model animals such as mice does not necessarily translate to human applications. Therefore, the continuing need for a bioethical perspective remains in terms of the possible implementation of therapeutic interventions, including feasibility, safety, cost/ benefit and accessibility.

But there are other challenges for bioethics in this field, some of which have received more attention than others. ${ }^{15}$ For example, given that IPSC are 'embryo-like' (although not totipotent) should there be any concerns regarding their creation and use? Could they be used to non-canonically derive human gametes in vitro and what should be the ethical framework for the clinical or research use of these cells? Could IPSC be used to form human chimaeras by mixing IPSC from two distinct donors, thus resulting in a single individual with a mixed genome that is not obtained by a fusion of gametes (as shown for mice)? Will the recently described direct differentiation of one somatic cell type into another, skipping a pluripotent IPSC intermediate stage, change any of the discussions? Clearly more (pro)active bioethics thinking should be welcomed at this stage, now that the embryo issue has been 'resolved'.

\section{CONCLUSION}

Posing doubts and formulating challenges in order to resolve objections or ethical uncertainties is a clear example of the healthy exercise in both ethics and science. In fact, the raising of serious ethical worries led scientists to look for solutions which avoided the destruction of human embryos; and that this effort possibly resulted in obtaining better outcomes from a scientific point of view. This strategy could perhaps be put to use in other similarly controversial fields.

In the case of cutting edge issues, which are still enveloped in possibilities and doubt, the problems must be presented unambiguously, so that ethical conclusions may be placed clearly and possible novel scientific solutions found. Commitment must be to the truth, a truth that is always provisional, refutable and questionable. Furthermore, the use of unfocussed images, poorly chosen simplistic metaphors and hyperbole should be avoided. In the words of Dietmar Mieth, ${ }^{46}$ 'the term 'stem cells' has become the magic password for entering a medical utopia where physicians will be able to overcome all human ailments once and for all. Viewed from another perspective, the dangers and limitations of stem cell research were also often similarly exacerbated, namely in debates that linked the status of the embryo with more vast considerations in terms of human life.

Another inherent question to this matter of hyperbole cannot be ignored: the fact that the dynamic imposed on these debates may create unfounded expectations or fears in vulnerable sections of society. Borrowing from Winston Churchill's famous observation on Russia, stem cell research has been 'a riddle, wrapped in a mystery, inside an enigma'. But, like all worthwhile enigmas, it can render truths, both expected and unexpected. How they are subsequently framed and used should be a welcome challenge for the future.

\section{CONFLICT OF INTEREST}

The authors declare no conflict of interest.

\section{ACKNOWLEDGEMENTS}

This work received partial financial support via Fundação para a Ciência e a Tecnologia FCT.

1 Patrão Neves MC: Autonomia e responsabilidade da pessoa; in Actas do IV Seminário do Conselho Nacional de Ética para as Ciências da Vida (eds) Poderes e limites da genética. Lisboa: Conselho Nacional de Ética para as Ciências da Vida, 1997; pp 3-8.

2 Durand G: Introdução Geral á Bioética: História, Conceitos e Instrumentos. Edições Loyola: Lisboa, 2003.

3 Whitney SN, Schneider CE: A method to estimate the costs of lives in ethical board review of biomedical research. J Int Med 2011; 269: 392-406.

4 Whitehouse $P$ : The rebirth of bioethics: extending the original formulations of van Rensselaer Potter. Am J Bioeth 2003; 3: 26-31.

5 Tristram Engelhardt Jr H: Bioethics critically reconsidered: living after foundations. Theor Med Bioeth 2012; 33: 97-105

6 Archer L: Bioética: avassaladora, porquê? Brotéria 1996; 142: 449-472.

7 Ramalho-Santos J: Science on the edge: some reproductive biology paradigms; in Santos BS (ed). Cognitive Justice in a Global World: Prudent Knowledge for a Decent Life. Lanham, MD, USA: Lexington Books, 2007; pp 251-269.

8 Thomson JA, Itskovitz-Eldor J, Shapiro SS et al: Embryonic stem cell lines derived from human blastocysts. Science 1998; 282: 1145-1147.

9 Shamblott MJ, Axelman J, Wang S et al: Derivation of pluripotent stem cells from cultured human primordial cells. Proc Natl Acad Sci USA 1998; 95: 13726-13731.

10 European Group on Ethics in Science and New Technologies (EGE). Opinion no 15 Regarding Ethical Aspects of Human Stem Cell Research and UseBrussels, 2000 in. http://ec.europa.eu/european_group_ethics/docs/avis15_en.pdf.

11 National Bioethics Advisory Commission (NBAC): Ethical Issues in Human Stem Cell Research. Washington, 1999 in. http://bioethics.georgetown.edu/nbac/stemcell.pdf.

12 Thomson JA, Odorico JS: Human embryonic stem cell and embryonic germ line. Trends Biotech 2000; 18: 53-57.

13 Figueiredo H: Aspectos técnicos da clonagem; in Gabinete de Investigação de Bioética da Universidade Católica Portuguesa (eds) Clonagem o risco e o desafio. Porto: Gabinete de Investigacão de Bioética da Universidade Católica Portuguesa, 2000; pp 15-22.

14 National Institutes of Health (NIH): Stem Cells: Scientific Progress and Future Research Directions. Maryland: Department of Health and Human Services, 2001 in. http://stemcells.nih.gov/info/2001report/2001report.htm.

15 Ramalho-Santos J: Human procreation in unchartered territory: new twists in ethical discussions. Hum Reprod 2011; 26: 1284-1287.

16 Hipp J, Atala A: Sources of stem cells for regenerative medicine. Stem Cell Rev 2008; 4: 3-11.

17 Broxmeyer H, Douglas GH, Hangoc G et al: Human umbilical cord blood as a potential source of transplantable hematopoietic stem/progenitor cells. Proc Natl Acad Sci USA 1989; 86: 3828-3832

18 Buchheiser A, Liedtke S, Leendert H, Looijenga J, Kogler G: Cord blood for tissue regeneration. J Cell Biochem 2009; 108: 762-768.

19 Kolata G: Scientists bypass need for embryo to get stem cells. The New York Times, 2007 in. http://www.nytimes.com/2007/11/21/science/21stem.html.

20 President Council on Bioethics: White Paper: Alternative Sources of Pluripotent Stem Cells. The President's Council on Bioethics, 2005 in. http://bioethics.georgetown.edu/ pcbe/reports/white_paper/.

21 Bjornson CR, Rietze RL, Reynolds BA, Magli MC, Vescovi AL: Turning brain into blood: a hematopoietic fate adopted by adult neural stem cells in vivo. Science 1999; 283: 534-537.

22 Wagers A, Irving J, Weissman L: Plasticity of adult stem cells. Cell 2004; 116: 639-648.

23 Roobrouck VD, Ulloa-Montoya F, Verfaillie CM: Self-renewal and differentiation capacity of young and aged stem cells. Exp Cell Res 2008; 314: 1937-1944.

24 Conrad S, Renninger M, Hennenlotter J et al: Generation of pluripotent stem cells from adult human testis. Nature 2008; 456: 344-349.

25 Kossack N, Meneses J, Shefi S et al: Isolation and characterization of pluripotent human spermatogonial stem cell-derived cells. Stem Cells 2009; 27: 138-149.

26 Kazanis I: Can adult neural stem cells create new brains? Plasticity in the adult mammalian neurogenic niches: realities and expectations in the era of regenerative biology. Neuroscientist 2012; 18: 15-27.

27 Jiang Y, Jahagirdar BN, Reinhardt RL et al: Pluripotency of mesenchymal stem cells derived from adult marrow. Nature 2002; 418: 41-49.

28 Testa G, Borghese L, Steinbeck JA, Brostle O: Breakdown of the potentiality principle and its impact on global stem cell research. Cell Stem Cell 2007; 1: 153-156.

29 Alikani M, Munné S: Nonviable human pre-implantation embryos as a source of stem cells for research and potential therapy. Stem Cell Rev Rep 2005; 1: 337-343.

30 Meissner A, Jaenisch R: Generation of nuclear transfer-derived pluripotent ES cells from cloned Cdx2-deficient blastocysts. Nature, 439: 212-215. 
31 Taei A, Gourabi H, Seifinejad A et al: Derivation of new human embryonic stem cell lines from preimplantation genetic screening and diagnosis-analyzed embryos. In Vitro Cell Dev Biol Anim 2010; 46: 395-402.

32 Hao J, Zhu W, Sheng C, Yu Y, Zhou Q: Human parthenogenetic embryonic stem cells: one potential resource for cell therapy. Sci China C Life Sci 2009; 52 : 599-602.

33 Robertson JA: Human embryonic stem cell research: ethical and legal issues. Nat Rev Genet 2001; 2: 74-78.

34 Bruce DM: Stem cells, embryos and cloning - unraveling the ethics of knotty debate. J Mol Biol 2002; 319: 917-925.

35 Carvalho AS: Comentário ao Protocolo Adicional à Convenção dos Direitos do Homem e da Dignidade do Ser Humano face às Aplicações da Biologia e da Medicina, que Proíbe a Clonagem de Seres Humanos; in Convenção para os Direitos do Homem e Biomedicina. Coimbra, 2008; Gráfica de Coimbra.

36 Takahashi K, Yamanaka S: Induction of pluripotent stem cells from mouse embryonic and adult fibroblast cultures by defined factors. Cell 2006; 126: 663-676.

37 Takahashi K, Tanabe K, Ohnuki M et al: Induction of pluripotent stem cells from adult human fibroblasts by defined factors. Cell 2007; 131: 861-872.
38 Amabile G, Meissner A: Induced pluripotent stem cells: current progress and potential for regenerative medicine. Trends Mol Med 2009; 15: 59-68.

39 Devolder K: Complicity in stem cell research: the case of induced pluripotent stem cells. Hum Reprod 2010; 25: 2175-2180.

40 Kim K, Doi A, Wen B et al: Epigenetic memory in induced pluripotent stem cells. Nature 2010; 467: 285-290.

41 Bock C, Kiskinis E, Verstappen G et al: Reference maps of human ES and iPS cell variation enable high-throughput characterization of puripotent cell lines. Cell 2011; 144: 439-452.

42 Gore A, Li Z, Fung H-L, Young JE et al: Somatic coding mutations in human induced pluripotent stem cells. Nature 2011; 471: 63-67.

43 Hussein SM, Batada NN, Vuoristo S et al: Copy number variation and selection during reprogramming to pluripotency. Nature 2011 ; 471: 58-62

44 Lister R, Pelizzola M, Kida YS et al: Hotspots of aberrant epigenomic reprogramming in human induced pluripotent cells. Nature 2011; 471: 68-73.

45 Cyranoski D, Ledford H: Simple switch turns cells embryonic. Nature 2007; 447: 618-619

46 Mieth D: Going to the roots of the stem cell debate. EMBO Rep 2000; 1: 4-6. 